\title{
A crise e a crença
}

\section{José Gil}

Universidade Nova de Lisboa

Lisboa, Portugal

josengil@sapo.pt

\section{Ana Godinho}

Universidade Nova de Lisboa

Lisboa, Portugal

anagodinhogil@sapo.pt

orcid.org/0000-0002-7929-4480

Resumo I Por que é tão difícil mobilizarmo-nos contra as alterações climáticas que representam um perigo iminente e radical para a humanidade? Este artigo analisa o círculo vicioso entre a indiferença perante as alterações climáticas e a procura da felicidade proposta pelo consumismo e a ganância capitalista. A consciência ecológica que se está a formar contra este estado de coisas. Cada vez é mais visível que a solução dos problemas locais depende da solução global. Para lutar contra os poderes políticoeconômicos que estão a destruir o planeta, é preciso acreditar que um outro mundo é possível. Como caracterizar esta crença na Terra, que não é nem religiosa, nem científica, nem ideológica? Por quantas mutações já ela passou e terá de passar? O outro mundo é afinal este mesmo - a Terra -, e é aqui mesmo, na urgência máxima da vida, que encontraremos as razões que temos de nos dar. Acreditar no mundo é acreditar no corpo.

PALAVRAS-CHAVE:

Alterações climáticas. Crença na Terra. Extinção da vida.

\begin{abstract}
The crisis and belief
Abstract I Why is it so difficult to mobilize against climate change which poses an imminent and radical danger to humanity? This article analyses the vicious circle between indifference to climate change and the search for happiness proposed by consumerism and capitalist greed. The ecological awareness that is being formed against this state of affairs. It is increasingly visible that the solution to local problems depends on the global solution. To fight the political-economic powers that are destroying the planet, it is necessary to believe that another world is possible. How to characterize this belief on Earth, which is neither religious nor scientific nor ideological? How many mutations has it gone through and will it have to go through? The other world is after all this one - Earth-, and it is right here, in the utmost urgency of life, that we will find the reasons we have to give ourselves. Believing in the world is believing in the body.
\end{abstract}

KEYWORDS: Climate change. Belief on Earth. Extinction of life.

\section{La crisis y la creencia}

Resumen I ¿Por qué es tan difícil movilizarse contra el cambio climático que representa un peligro inminente y radical para la humanidad? Este artículo analiza el círculo vicioso entre la indiferencia ante el cambio climático y la búsqueda de la felicidad propuesta por el consumismo y la codicia capitalista. La conciencia ecológica que se está formando frente a este estado de cosas. ¿ Cada vez es más visible que la solución a los problemas locales depende de la solución global. Para luchar contra los poderes político-econômicos que están destruyendo el planeta, es necesario creer que otro mundo es posible. Cómo caracterizar esta creencia en la Tierra, que no es ni religiosa ni científica ni ideológica. ¿Cuántas mutaciones ha atravesado y tendrá que atravesar? El otro mundo es después de todo éste, la Tierra, y es aquí mismo, en la máxima urgencia de la vida, donde encontraremos las razones que tenemos para darnos. Creer en el mundo es creer en el cuerpo.

PALABRAS CLAVE: Cambio climático. Creencia en la Tierra. Extinción de la vida.

Enviado em: $27 / 10 / 2021$

Aceito em: 03/11/2021

Publicado em: 29/11/2021 
O que se aproxima aí não tem nome. A probabilidade da extinção próxima da espécie humana não se chama Apocalipse nem Armagedom, como se devêssemos ir ao arquivo do passado buscar a palavra capaz de nomear tal acontecimento para memória futura. Mas, desta vez, não haverá palavra para o dizer nem história para o situar. Não haverá alguém para o pensar. Não haverá memória do futuro, porque este terá deixado de existir. Desaparecerão os arquivos. Só o silêncio planará sobre o planeta, para ninguém.

Morrem hoje, anualmente, mais de 8,7 milhões de pessoas por causa da poluição atmosférica, que mata bebês e crianças em todos os países. Em breve, haverá regiões inteiras da Terra em que será impossível respirar. Um sufoco planetário ameaçará os humanos. Os furacões, as secas, os incêndios, as inundações deixaram de ser fenômenos irregulares e dispersos pelo globo, tornaram-se mais intensos, mais frequentes e mais devastadores, atingindo ao mesmo tempo países e continentes inteiros. A aceleração exponencial das mudanças climáticas, considerada como uma característica do Antropoceno, é imparável e sem lei. A biodiversidade diminui drasticamente ameaçando a ecologia humana, o aumento da temperatura dos mares destrói a ecologia animal, o degelo dos polos e dos glaciares transformará radicalmente o clima e o modo de vida. A desflorestação mundial ultrapassará os limites do equilíbrio ambiental: as queimadas produzirão mais carbono do que o que absorvem da atmosfera.

São fatos anunciados pela ciência, não profetizados por crenças religiosas irracionais. Se tantos (como os jovens na manifestação de Paris de março, 2021) falam já de "fim do mundo", é porque lutam para que ele não acabe, para que o alarme ecoe no presente e não se apague. O espectro do fim do mundo assombra o planeta. E, no entanto, apesar de tantos avisos e sinais cada vez mais ameaçadores de catástrofes globais, a opinião pública e os dirigentes políticos mundiais pouco fizeram para mudar o atual estado de coisas. Por que é que não se dá a atenção devida a um perigo tão iminente e tão grave - na verdade, o perigo máximo para a humanidade -? Por que é que as populações e os políticos não se mobilizam contra as alterações climáticas?

A ameaça da crise ambiental é de tal ordem que ela obriga a pensar diferentemente o tempo, a morte, a comunidade humana e a sua relação com a Terra. As figuras e os temas tradicionais do pensamento filosófico - o ser e o nada, o sujeito, a verdade, o mundo, o conhecimento, a liberdade, o bem e o mal -, recentemente postos à prova em sucessivas tentativas de desconstrução, desmoronam-se agora graças a sismos que não ocorrem no interior do pensamento, mas vêm do exterior, como fatores exógenos. E se somos levados a pensar diferentemente é, também, por uma necessidade extrínseca, pela exigência biológica de sobrevivência. Isto porque a eventualidade de uma catástrofe radical atingir a humanidade inteira, extinguindo-a, levanta a questão: "como chegamos até aqui? O que fizemos e pensamos - e agimos como pensamos - que nos trouxe à beira do abismo?" Questões que põem em causa toda a nossa história e a nossa maneira de a pensar e nos pensar.

Se estas perguntas se impõem hoje com uma força inesperada é porque no nosso presente nada anuncia uma mudança de rumo, enquanto os sinais ameaçadores se acumulam aceleradamente. E por que é que, apesar do alarme 
que atravessa todas as nações, apesar dos avisos das organizações internacionais e dos cientistas independentes, nenhuma ação decisiva é tomada pelos poderes políticos do mundo inteiro? Por que é que se deixam viver as populações na fé de que nada de grave acontecerá, e que os perigos das alterações climáticas serão naturalmente afastados por esta mesma marcha da história que transporta o nosso presente? Cruzam-se aqui três fatores que contribuem para manter a santa inércia do tempo histórico: os interesses econômicos do tecno capitalismo global, a submissão política, total ou parcial, a esses interesses, e o imobilismo inato dos povos.

Uma dinâmica específica faz mover estes três fatores, alimentando o círculo vicioso que os encadeia. A conivência da economia e da política resulta, aqui, de um mesmo objetivo: o ideal do crescimento econômico ilimitado e o ideal político de uma melhoria contínua da "qualidade de vida" confundem-se na convicção de que o ideal coletivo está já encarnado no presente e no futuro nele inscrito. Esta ilusão vem naturalmente sobrepor-se e coincidir com a convicção primeira de que existir, estar vivo, por si, sem mudança nem devir, tem um valor absoluto inquestionável. O ideal do presente, no discurso coletivo, vive-se agora como valor existencial: é melhor continuar e conservar do que mudar e transformar. E, é claro, a prática, individual e social, da manutenção do presente reforça a estabilidade sistêmica do conluio entre a economia e a política que a induz, isto é, que induz a convicção de que se escolhe livremente uma tal prática. (Este esquema não exclui a produção regular de mudanças dentro da estabilidade geral sistêmica).

Ora, essa mesma certeza de que a vida é melhor do que a morte exclui a ideia da morte enquanto nada, levando à negação do "fim" da vida e, assim, à prática de um tempo de vida imortal. A crença na imortalidade não é apenas um fenômeno psicológico e individual, tem efeitos na produção da realidade. Funda a cultura e a criação, porque permite a memória e os ritos. Se individual e coletivamente nascem comportamentos de manutenção das inércias quotidianas a que chamamos "pequenas imortalidades" - e só elas permitem suportar o mal viver assegurando a continuidade do tempo -, há também a "grande imortalidade" dos ciclos e sequências históricas que resgatam da morte os povos e as nações. O que tem sentido, o acontecimento, é o que escapa à morte, isto é, ao desaparecimento absoluto, pela formação de uma imagem duradoura, imortal de si mesmo. Imagem equívoca que, no entanto, é exibida como uma prova (sinal) unívoca de verdade. Tal é a imagem que os homens fazem de si mesmos e do mundo através das culturas que fabricam.

Note-se que nunca como agora se quis apagar tão freneticamente a consciência da morte dos gestos e do tempo quotidiano. Não só se reduziram ao mínimo as cerimônias fúnebres, não só se pensa e se trabalha seriamente, isto é, cientificamente, em técnicas para impedir o envelhecimento, mas vive-se num desejo permanente de imortalidade: desde o prazer imediato, familiar ou tribal, da casa, do carro, da gastronomia e do turismo, do consumo de bens e de imagens, até à letargia simples de se sentir vivo (e, portanto, de sobreviver, quer dizer, de ser, de certo modo, imortal) no meio de tantas mortes, guerras, desastres e flagelos, aspira-se a permanecer num presente fechado em si mesmo, autossuficiente e autocomplacente, seguro, invulnerável. Só aberto ao futuro na medida em que este o dilata e aumenta. Um presente que implica também a saúde e a segurança no emprego: compõe-se 
então a imagem da felicidade. Assim vão os homens e mulheres das sociedades ocidentais. Assim se protegem, envolvidos em pequenas imortalidades que suportam o seu ideal de felicidade. De que a morte é radicalmente excluída.

É a crença na imortalidade - nas suas diferentes manifestações -, essencialmente, que impede de responder à urgência do perigo das alterações climáticas. $\mathrm{E}$, no entanto, estas confrontam-nos hoje com um não-acontecimento absoluto, ou melhor, com uma espécie de acontecimento - a extinção da humanidade - que, mesmo antecipando-o, já não é possível contornar, recobrir ou mascarar com a crença na imortalidade. Neste sentido, é o próprio pensamento que ameaça explodir antes de tempo.

É a morte da humanidade que se perfila no horizonte da catástrofe climática. Os poderes econômicos têm o maior interesse em manter, reforçando-o e renovando-o constantemente, o feitiço que entorpece os consumidores na pequena imortalidade, entretidos que estão na esperança de serem felizes. Para tanto, continuam a perfurar a terra, desflorestá-la, poluir o ar e a água, produzir mercadorias que atraem e enfeitiçam, a criar imagens e gestos cada vez mais sedutores e imprescindíveis. Um círculo que se estreita progressivamente vai captando as pessoas, que passam a fazer parte do seu envolvimento: devasta-se a terra, mas para fabricar bens e objetos necessários ao bem-estar de cada um, de tal modo que o trabalho e o lazer, o esforço e o prazer, se ligam cada vez mais diretamente às alterações climáticas. Os empregos dependem de atividades que, de longe, mas cada vez mais perto, contribuem para o efeito de estufa ou o aumento de carbono e metano na atmosfera. O turismo de massa, as viagens, os grandes eventos culturais e desportivos implicam automaticamente mais poluição e mais degradação do ambiente. Para gozarmos da nossa parte de bem-estar, devida e merecida, temos necessariamente, e sem disso nos darmos conta, de participar na grande empresa civilizacional de destruição do planeta. Viver tornou-se uma tarefa assassina e, ao mesmo tempo, suicidária.

Isto leva, claro, a uma grande dificuldade em reconhecer a iminência do perigo das alterações climáticas. Pertencemos ao sistema que leva a esse perigo, trabalhamos dentro e para o sistema, gozamos e queremos mais do que ele nos oferece. Múltiplos círculos viciosos encadeiam-se em espiral, a partir de um só, que envolve os outros: quanto mais se deseja viver bem, mais o esforço acrescido acelera o movimento do sistema e mais o nosso desejo se prende nas malhas do que nos é proposto. Não há alternativa para a ideia de felicidade, de uma outra "vida melhor", de outros estímulos e prazeres. É, pois, uma ideia diferente de bem-estar e felicidade - uma outra mentalidade - que se tornou urgente forjar.

Ela está já a formar-se por toda a parte. Sempre que uma catástrofe se abate sobre um país, uma região, sempre que as imagens trágicas dos efeitos de um furacão ou de inundações ou de incêndios cobrem de feridas os ecrãs de televisão, nascem inúmeras vontades de tudo mudar. A consciência ecológica que exige transformações radicais da economia e da política mundial, e do modo de vida correspondente dos povos, contamina e alastra pelo planeta. O fantasma de um outro mundo possível assombra os homens e mulheres de todos os continentes.

O modo como as mudanças ambientais se manifestam condiciona as transformações das mentalidades. A situação atual é de mudança: por um lado, as transformações climáticas têm ainda efeitos visíveis irregulares, sem nexo entre eles 
e sem relação a uma causa: os incêndios terríveis que arrasam a Califórnia todos os anos não revelam nenhum fio que os religue aos incêndios da Austrália, nem as cheias que devastaram o sul de Moçambique em Março de 2019 parecem relacionarse com os degelos dos glaciares da América e da Europa. As temperaturas elevadas, as secas, as pandemias são consideradas irregularidades normais que pontuam a regularidade meteorológica habitual. Não se veem ainda claramente as ligações dos efeitos entre si, nem as conexões com o fenômeno designado por "alterações climáticas". As relações de causa e efeito identificadas pelas cientistas são pouco visíveis pelos homens comuns. Estes, mesmo quando são vítimas, não têm a percepção de causas não naturais por detrás das catástrofes concretas.

Mas, por outro lado, a particularidade do caos ambiental que se está a instalar vai apontando para um certo tipo de soluções. No cômputo geral dos flagelos que assolam a terra, o caos cresce exponencialmente e as suas consequências imediatas tornar-se-ão em breve mais alarmantes do que o sentimento de ordem estável e duradoura. Tanto mais que qualquer destruição tem um eco maior do que o ramerrão dos gestos quotidianos. A ansiedade e o sofrimento provocados pelas alterações climáticas sobrepor-se-ão rapidamente aos prazeres das pequenas imortalidades rotineiras. Paradoxalmente, precisamente por estas razões, começar-se-á (se não se começou já) a atribuir os males ecológicos a uma causa única, invisível, mas insistente, que afeta o conjunto da vida dos indivíduos. Assim como a dimensão existencial compreende todas as outras, o caos que a atinge unifica todos os outros: os efeitos ambientais, as rupturas sociais, as patologias psíquicas vêm de um mal geral que atingiu todo o planeta e a nossa relação com ele. Projetaremos, magicamente, numa só instância, a causa da pluralidade de sintomas que nos perturbam sem cessar.

A ciência diz-nos uma coisa simples, fácil de compreender: os fenômenos climáticos e os fenômenos humanos conectam-se intimamente, como numa rede, num corpo ou num rizoma. O efeito de estufa da atmosfera aquece os oceanos e arruína os ecossistemas marinhos, faz derreter as calotas de gelo e os geleiras, o que leva à subida do nível dos mares, afunda campos e cidades, desloca populações inteiras e traz o caos econômico, social, político e ambiental. A curto e médio prazo, as desigualdades aumentarão, a injustiça e o crime crescerão, as revoltas e sublevações políticas alastrarão, desencadear-se-ão guerras e repressões violentas. E quanto mais descontroladamente estes efeitos se manifestarem, mais as ações humanas contribuirão para a destruição da ecologia do planeta. Um sofrimento global inimaginável emanará da terra.

Qualquer que seja a ponta por onde se lhe pegue (a erosão da biodiversidade, a utilização dos combustíveis fósseis ou a libertação de metano devido ao degelo do permafrost) envereda-se sempre por um sistema em rede que envolve todas as dimensões da existência humana e se volta contra si próprio, num círculo finalmente suicidário. As alterações climáticas estão a um passo de se tornar a causa maior unificadora dos males do mundo. Isto não é por acaso. Estamos, na realidade, a descobrir praticamente que na raiz das desigualdades e da injustiça, que existem desde que se constituíram sociedades humanas e que as atuais não fazem mais do que prolongar, está a ruptura de um laço essencial com a terra (a que nós chamamos tradicionalmente "natureza"). Por mais diversos que tenham sido os fatores que contribuíram para a formação de poderes religiosos e políticos baseados na 
"exploração do homem pelo homem" (subjugação da maioria por uma minoria, extração e apropriação da riqueza produzida pelo trabalho de uns para benefício de outros) - desde a invenção da agricultura ou o desenvolvimento da técnica até ao crescimento da demografia -, foi sempre o livre horizonte da posse e do aproveitamento destruidor dos recursos naturais que permitiu, alimentou e induziu todas as formas, passadas e presentes, de contrato social injusto.

Até hoje, não se adivinhavam as ligações entre a destruição ecológica e a injustiça social. As mediações entre uma e outra eram tantas que era difícil associálas. Atualmente, elas vão caindo progressivamente de tal modo que é possível estabelecer laços visíveis entre, por um lado, a extração e o refinamento do carvão e do petróleo, a desflorestação, a cultura intensiva, a indústria agroalimentar, a pesca desenfreada e a liquidação ilimitada dos habitats marinhos e terrestres, e por outro, as perturbações socio-existenciais que afetam as populações mundiais. Como se, o que parecia anteriormente solto e desligado, aleatório e acidental, aparecesse agora regido por um determinismo cada vez mais opressor: os laços entre os fenômenos da natureza, de uma natureza instrumentalizada e desviada por nós, e os fenômenos sociais e humanos, tornaram-se evidentes e determinados, enquanto relações de causa e efeito.

Não se trata só de constatar que o funcionamento acelerado da economia capitalista provoca efeitos necessariamente devastadores em todos os planos, é toda uma revolução da nossa própria ideia de uma vida boa e justa que nos leva a repensar o tipo de existência a que os sistemas econômicos, políticos e sociais nos condenaram: queremos uma outra forma de coesão comunitária, uma outra prática da justiça que se funde na, e promova a igualdade, e um viver que permita a livre expressão das singularidades individuais e coletivas. Rejeitamos os modos de vida a que somos cada vez mais obrigados, descobrindo que eles foram engendrados para satisfazerem, adequada e automaticamente, as necessidades financeiras dos sistemas que os produzem. É em nome de uma visão nova da vida, em gestação por todo o lado, que se critica a cegueira que impede de ver a ligação estreita e direta entre o regime econômico vigente, a destruição do planeta, o caos e o sofrimento das pessoas.

A iminência do perigo a que estamos expostos força o pensamento a recusar as desconstruções especulativas e os jogos fátuos das ideias inúteis: não temos tempo, a morte bate à porta. Por que, então, escrever em vez de agir, como estamos agora mesmo fazendo? Não para fixar uma situação, pois não haverá mais memória, futura ou presente, nem para conjurar magicamente a catástrofe provável. Escrevemos, sim, para nos aproximar dela, simulando-a para poder conceber a ação mais exequível, mais perto das possibilidades concretas dos seres humanos.

A própria questão da pertinência do pensar conduz imediatamente à da sua utilidade, isto é, à da sua aplicabilidade pela comunidade humana. Nas condições em que estamos imaginando um futuro da Terra a que já não pertencemos, e, portanto, convencendo-nos de um presente em que já não somos "o povo de Deus", mostrando-nos que nada serve recorrer a transcendências divinas, fazendo-nos ver quão abandonados estamos, em derrelição real porque agora sim, Deus morreu ou está prestes a morrer - e nós ficamos entregues exclusivamente a nós próprios, perante a Terra em destruição que ameaça extinguir-nos. O único recurso possível, a última réstia de força concreta que nos pode animar, é o nosso laço com essa Terra 
- e ele tem um nome, imanência. É só reconstruindo, de outra maneira, esse laço que poderemos lutar contra o desaparecimento total que nos ameaça. E como forjar uma nova ligação à Terra?

Destruímos o nosso elo com a Terra como estamos a destruir, talvez, a nossa capacidade de nos regenerarmos. A transformação, com prejuízo das boas qualidades das forças econômicas, dos sistemas de poder e do desenvolvimento tecnológico vão num sentido de evolução temporal caótico e imprevisível. Não há salvaguardas. As relações com o espaço e o tempo complicam-se e produzem perturbações demasiado aceleradas e hostis à criação e à manutenção da vida.

A dimensão da exposição à catástrofe (pandemias e alterações climáticas) é ainda, em parte, desconhecida. Sabemos de alguns efeitos que parecem estabelecer relações de contaminação entre umas e outras e produzir um efeito dominó - da transmissão dos vírus até à desflorestação global, passando pelo lixo mais que pandêmico, o solo, os oceanos e os rios, o ar, por exemplo.

Mas é cedo para sabermos qual o impacto real na saúde em geral, nas relações sociais, no quotidiano, na cultura global, nos corpos, no planeta inteiro. A gravidade dos problemas aparecerá ainda mais nítida e transformará a terra, os modos de vida, os comportamentos e o pensamento. As promessas de muitas soluções e acordos estão ainda longe de serem aceitáveis e nos tranquilizarem. As violências imparáveis de todo o tipo não se conseguem tornar normais. Não há conforto possível. Os tempos são realmente ameaçadores. Que crença nós temos de criar para acreditarmos na possibilidade de preservação e sobrevivência na Terra?

Arrancamos da Terra a vida e não a arrancamos de um outro elemento qualquer. A Terra é o espaço e o tempo da vida. A Terra é espaço-tempo que, em certas condições iniciais de instabilidade, inventa e é criadora. A Terra não é uma mercadoria alienável apesar de todos os dias fazermos como se fosse. Ela é um corpo e é atravessada por todas as matérias instáveis, algumas mesmo impossíveis de codificar. Ameaçada pelas atividades humanas, responde com alterações que tornam a vida em geral mais difícil e podem ser irreversíveis. Uma tomada de consciência não é suficiente porque na situação presente parece não haver muito tempo para adaptações lentas. A Terra, voltamos a repetir, não é mercadoria alienável, não é propriedade dos homens.

Tomar a cargo de forma crítica e ativa o que está a acontecer, compreender e agir segundo a gravidade da situação é mais do que uma possibilidade real, é agir com base no que é urgente, necessário e imediato. Quer dizer, tomar, com determinação absoluta, para si e para o planeta inteiro, o corpo como ele é, que nunca está somente no presente, mas, imanente, é capaz de conter o antes e o depois, a fadiga, a expectativa e até o desespero. A Terra é ela própria o elo e o corpo que se parte a cada instante.

Perante a lentidão e ineficácia hipócrita das respostas planetárias parece ter de ser uma onda de choque, um movimento tal que não possamos mais continuar a dizer e a fazer as mesmas coisas. Enquanto o choque não for suficiente caímos num "arbitrário sanguinolento" (DELEUZE, 2006, p. 213) e continuamos com os mesmos tiques lógicos, sociais, econômicos e políticos, com as mesmas falsas soluções que aumentam as desigualdades, as injustiças e tornam intoleráveis as relações dos seres vivos entre si e com o meio. Corremos sempre riscos. O Choque demasiado violento pode também fazer-nos falhar completamente a nossa ligação à Terra. 
Debatemo-nos quotidianamente com uma impotência do pensamento que se propaga e tem efeitos diretos na ação e nos corpos. Uma "estranha petrificação" diz Deleuze. Se por instantes o mundo se suspendeu (nos primeiros meses de 2020), diante de uma onda que parecia demasiado violenta, e o pensamento se encolheu e emperrou, foi só por um segundo, porque voltamos ao "mesmo" intolerável "normal" (o que muita crítica global considera há muito obsoleto e mortífero). E não é coisa de instantes a constatação e a confirmação da "ruptura do elo do homem e do mundo" (DELEUZE, 2006, p. 219) e do estilhaçamento que torna o intolerável uma coisa banal. A quebra do elo deixa-nos doentes e impotentes, dessolidariza-nos. "O homem não é ele próprio um mundo diferente daquele em que experimenta o intolerável e se encontra imobilizado" (DELEUZE, 2006, p. 221), mas age como se fosse único. Não para de fazer coincidir o centro do seu ego com o centro de gravidade da Terra como se tudo fosse plano e imóvel, ignorando ou fazendo de conta que a Terra não tem a sua própria aceleração e as suas próprias forças.

Perdido o elo, temos mais frio, mais calor, mais fome, mais sede, mais cansaço, mais desânimo, mais doenças, tudo é rápido demais para podermos nos adaptar. A empatia com o mundo desaparece, como a própria possibilidade de respirar. Sufocamos na ausência do elo partido. Os nossos neurônios espelhos não encontram interlocutor, tornam-se raros e inativos. Os nossos corpos isolam-se, desamparam-se. O nosso cérebro também muda. Escasseiam as sinapses, aumenta a indiferença, como aumentam os juízos negativos, a desconfiança, a impossibilidade de viver. Rejeita-se a terra que também nos rejeita e aumenta a sensação de terror, sente-se a aproximação do cheiro da morte. A nossa angústia por não poder escapar à irreversibilidade da morte aumenta exponencialmente. E respondemos ao perigo, a qualquer coisa que não se consegue modificar, desconectando-nos em todos os sentidos. Fazemo-lo diferentemente, orientando-nos por coordenadas que não compartilhamos (as angústias dos mais novos não são as mesmas dos mais velhos), não exprimimos nem conseguimos comunicar verdadeiramente. A morte na sua irremediável ligação com a terra escapa-nos e estamos a perder tudo. Porque também é verdade que já não acreditamos em nada, nem no que acontece, nem no que pensamos ou fazemos, ouvimos ou observamos. Uma espécie de alucinação global de imunidade, de proteção iluminada e louca, diz-nos que nada já nos diz respeito.

Mas a terra, os corpos e as vidas persistem ainda, mesmo que tenham perdido a coincidência dos seus centros. Tudo se mistura e dissolve. Quer dizer, no seio mesmo do que se transforma e muda, em aproximação ao elo que constitui a vida, a saúde e a evolução, surge a destruição mortífera e irreparável.

O que nos dizem os que já morreram? O que nos passa pela cabeça quando encontramos a morte? Não conseguimos ver sempre bem, mas já a experimentamos tantas vezes e de tão diferentes maneiras (pequenas mortes, morte na literatura, na religião, na arte, no quotidiano, a morte dos outros): na ficção, na imaginação, na percepção, na memória, que de algum modo poderíamos fazer diferente. Sem carpir, sem acompanhamento coletivo dos mortos até ao seu último território, sem enterramento, abandonamos rituais milenares comuns a todas as culturas, normalizamos numa ação simplificada e asséptica o que antes passava por tantos passos, tantos gestos intermédios, tantos corpos. Os mortos dizem-nos que estamos a deixar só vazios e abstrações. 
O elo partido estendeu-se cruelmente até aqui. Já não há um mesmo território delimitado ou isolado, os restos dos corpos evaporar-se-ão simplesmente no ar insuportavelmente quente e irrespirável. Utilizam-se esquemas de desaparecimento mais curtos e técnicas mais econômicas e tecnológicas de gerenciamento de afetos, de tempos e de espaços. A Terra não é a mesma. As cinzas espalham-se por todo o lado que é lugar nenhum.

Para continuarmos a existir, o corpo (a Terra) tem de comprometer-se numa continuidade de perseverança, numa duração, segundo os acasos dos fenômenos e dos acontecimentos, que exige torções, desacelerações e deslocamentos e acima de tudo, uma "conversão da crença": "na nossa universal esquizofrenia temos necessidade de razões para acreditar neste mundo" (DELEUZE, 2006, p. 222).

O que não é imediatamente perceptível tem de ser intensamente vivido no corpo e não pode ser confundido com outras causas. A Terra pode bem permanecer para além de nós, porque não é uma matéria qualquer, mas para a continuarmos a habitar, para haver humanos na Terra, é necessário perceber bem os limites dos recursos e os da sua destruição. Se as alterações climáticas produzidas por nós atravessarem o limite das possibilidades a resposta seria muito simples: não poderemos mais continuar a existir. Não faremos mais a coincidência do centro do ego com o centro de gravidade da Terra.

Não é necessário que "eu" exista, mas se continuo a existir garanto transitoriamente que a Terra e o tempo continuarão também. É a sensação mais intensa e inexplicável.

Só na Terra e no tempo, ligados entre si, perceberemos a contingência dos encontros. A vida inscreve-se na matéria segundo uma multiplicidade de processos que a todos os níveis se encadeiam uns nos outros. A vida é a regra em certas condições e estados específicos de não equilíbrio. Preservar a vida da Terra é preservar a nossa própria vida, o que nem sempre é fácil de ver. Talvez magicamente continuemos a pensar ou a querer pensar que a Terra tem uma capacidade infinita para se autorregenerar. De cada vez que lhe infligimos uma ferida ela cura-se. Seguindo esta lógica que já vimos muitas vezes funcionar, mesmo que a extensão e qualidade da ferida fosse ultrapassada, tudo funcionaria em favor da continuação da vida. Mas o pensamento mágico é insuficiente, existem feridas irreversíveis. Teremos então de fixar e respeitar certos limites para que os equilíbrios terrestres continuem?

Compreendemo-nos na Terra, incluindo-a necessariamente. Como um corpo é habitado e é ele próprio local de vida habitável se o destruirmos, é simples, nos extinguimos e possivelmente levamos conosco os outros organismos vivos, a Terra inteira. Mas, como mudar as perspectivas, os temperamentos e as vontades?

O que vivemos neste momento é quase instantaneamente mundial, a pandemia, as mudanças climáticas, o ar que nos envolve, a água, a comida, têm também esse grau de generalidade. O "não consigo respirar" somos todos nós a dizer! Não consigo alimentar-me, morro à sede, não tenho casa. Qualquer coisa não está a correr nada bem. E mesmo que alguns não o tenham vivido ou não queiram pensar nisso, já experimentamos o suficiente para podermos acreditar. Já temos uma longa experiência de reparação e regeneração. Já estabelecemos relações de causa efeito com índices de poluição, do aumento descontrolado da temperatura.

Não estamos à procura do segredo ou da essência da vida, não temos sequer uma fórmula adequada, um algoritmo mágico. Mas esforçamo-nos por compreender. 
Sabemos, no entanto, de características gerais, das suas formas de manifestação, reconhecemo-las. Certas propriedades dos seres vivos convêm-nos a todos. Plantas, animais, minerais, por muito diferentes que sejam, são todos atravessados por uma mesma corrente de matéria que lhes permite respirar, alimentar-se e existir. Só a morte rompe este elo. A vida deixa de aí estar nesse instante. Todas as partes, todos os elementos, se tornam subitamente estrangeiros uns aos outros, sem elos, sem solidariedade, não resistem aos efeitos da dissolução.

\begin{abstract}
"Donde, é o elo que se tem de tornar objeto de crença (...) A crença já não se dirige a um mundo outro ou transformado. (...) só a crença no mundo pode ligar o homem àquilo que ele vê e ouve. (...) O que é certo é que acreditar já não é acreditar num outro mundo, nem num mundo transformado. É somente, é simplesmente acreditar no corpo. É entregar o discurso ao corpo, e para isso atingir o corpo antes dos discursos, antes das palavras, antes que as coisas sejam nomeadas: o "nome", e mesmo antes do nome. Artaud não dizia outra coisa, acreditar na carne, "sou um homem que perdeu a vida e que procura por todos os meios retomar o seu lugar" (DELEUZE, 2006, p. 223).
\end{abstract}

O conceito de crença, tantas vezes pensado volta aqui como nosso problema por várias razões. Sob a forma de pergunta que num contexto muito próprio se faz deste modo: como é possível, dadas as condições de intolerabilidade, conceber uma nova maneira de viver? Por detrás desta pergunta estão as alterações climáticas, a crise ecológica, a Terra e a nossa relação com ela e o modo como as vamos pensando, reformulando, as respostas que encontramos, mas também as denegações e vazios que nos fazem entrar em becos-sem-saída. Que percepções temos hoje que não tínhamos há quase dois anos? Ou que já não temos e tínhamos há 3000 anos?

Há problemas para os quais não estamos preparados, nunca estaremos, outros para os quais não estamos dispostos a fazer cedências. Parecem novos, embora a novidade não seja assim tanta, e relacionam-se uns com os outros. Deixaram de ser percebidos localmente e de forma isolada e parecem exigir medidas radicais e globais. Como afirmar a vida? A pergunta não deixa de ser simples!

Vivemos num só e mesmo mundo e dele precisamos de ter uma compreensão que não rompa a unidade do seu sentido. Mas uma espécie de incerteza e imprevisibilidade atravessa-o e mina todas as relações. A questão da crença volta por "necessidade pura", não é uma questão qualquer, joga-se sempre num momento preciso - entre a vida e a morte - quer dizer, joga-se, simultaneamente e sem dualismos, no instante da micro percepção de que se caminha com a recusa de olhar face a face os vários tipos de catástrofes, (recusa que se acompanha de uma infantilização e anestesia das opiniões, que se manifestam em negacionismos proliferantes), e no ínfimo momento de perplexidade perante a sua indestrutível simplicidade e na forma direta como se apresenta.

O que foi que aconteceu às crenças todas que já tivemos? Não são elas atitudes básicas?

Claro que podemos reduzi-las a uma forma de adesão ou assentimento pouco certa, ou mesmo irracional, desvalorizando-as. Já as substituímos vezes sem conta. Já as remetemos para subterrâneos insondáveis. Deleuze, em 1986, num outro contexto, refere-se a um fato que diz ser moderno sobre a crença: o de já não acreditarmos em nada. 
Durante muito tempo pudemos dizer que de tempos a tempos se revelavam parcialmente diante dos nossos olhos os limites que chegavam ao horror, ao mais insuportável (a SIDA, Chernobyl, outras catástrofes ambientais e epidemias). Mas nos últimos anos o processo tomou uma aceleração que é impossível não ver ou sentir, já não são revelações parciais. Do permafrost, às barreiras de corais mortas, à extinção precipitada de espécies, aos degelos impensáveis dos polos, à falta de água potável, à escassez de alimentos, à subida do nível dos oceanos, às poluições generalizadas, ao aquecimento global descontrolado, às desflorestações e suas consequências, a lista parece infindável. Deixou de ser de tempos a tempos e todos os dias temos notícias, alertas, constatamos na própria carne as catástrofes, vivemolas de mais perto, sofremo-las na pele, morremos aos milhões por causa delas. E, no entanto, ousamos dizer que não acreditamos no que está a acontecer. Ou como diria Deleuze só acreditamos pela metade. A outra parte de nós continua como se nada fosse. "O fato moderno é que nós já não acreditamos neste mundo. Nós nem sequer acreditamos no que nos acontece, o amor, a morte, como se nos dissessem respeito só por metade" (DELEUZE, 2006, p. 221).

Porque aquilo que nos acontece não nos pertence ou só nos diz respeito pela metade.

E é por aí mesmo que voltamos à questão da crença e a consideramos absolutamente necessária. Não a uma ideia de crença como algo que está nos limites dos nossos conhecimentos, chegando mesmo a opor-se à razão e à ciência, não a uma ideia que se confunda com o conceito de fé religiosa. Não há um credo, não se trata de uma convicção íntima, de uma relação privilegiada com Deus. Nem mesmo se trata de uma substituição de uma coisa por outra. Como não se trata de um tipo de adesão ou assentimento. Nem de algo assimétrico a que não se pode escapar quando se está em posição de inferioridade (social, intelectual e cultural), como pensa Bruno Latour (2007).

As dificuldades para a caracterizar surgem a cada tentativa de nomeação: se é um estado mental não observável, subjetiva, se perpetua o pensamento dicotômico, se entra no quadro da doxa platónica ou no quadro da filosofia cartesiana, se é uma crença noutro mundo, se é uma questão de transcendência, de relação com uma divindade qualquer. Podíamos prosseguir neste sentido dado que tanto já se disse sobre a crença.

Apesar destes obstáculos e de outros que não nomeamos, a crença surge inevitavelmente. Perguntamos frequentemente: o que nos falta para acreditarmos mesmo no que está a acontecer e não só pela metade?

A crença não é só um estado mental ou psicológico, é uma disposição particular para agir, sem mediações, sobre essas metades separadas de nós mesmos. Tomada de forma não limitada nem contextualizada, só ela com a prática se sustenta. E pode escapar-se aos grilhões que a amarram à normalização da opinião. Podemos até considerar como David Hume que a crença é um "não sei que" que cada um sente suficientemente (DELEUZE, 1953, p. 12).

Possivelmente a crença situar-se-á sempre, paradoxal, fora da consciência, num lugar desconfortável, em desequilíbrio, numa relação nunca simples com a verdade e a representação. Por isso, já a substituímos, confrontamos, deslocamos, mascaramos ou simplesmente subestimamos. Já pensamos que o seu território era só religioso, já a abandonamos. Gostaríamos de a pensar numa relação com o corpo, 
nascendo dele, e com ele dispondo-se para o movimento singular que é afirmação da vida. Espécie de confiança ou franqueza que surge e desaparece numa hora determinada e se traça numa linha sem contorno. "É a hora em que se diz: «Era mesmo isso, mas não sei se o disse bem, nem se fui suficientemente convincente.» $\mathrm{E}$ apercebemo-nos de que pouco importa termos dito bem ou termos sido convincentes, porque de qualquer maneira agora é mesmo isso" (DELEUZE; GUATTARI, 1992, p.10).

O elo em falta, que reconhecemos que nos enfraquece e não parece vir a ter solução pelo fato de o sabermos, talvez se reate nessa "não sei que" que cada um sabe e que escapa ao conhecimento e à fé.

E o movimento torna-se infinito quando a crença se torna crença neste mundo e se realiza nele. Mas qualquer coisa, num tempo muito longo, nos aconteceu que traz a questão mais uma vez: "Uma ruptura do elo do homem e do mundo" (DELEUZE, 2006, p.219), uma enorme falta ou um deslocamento da crença, que veio do medo, das ameaças contínuas e persistentes ou do conforto do instantâneo, da comunicação virtual permanente, num tempo mais curto e mais pequeno do que é possível medir, ou ainda de um cansaço, tudo isso nos tornou indiferentes e passivamente descrentes. Os dados científicos cada vez mais precisos não são suficientes para nos pôr em movimento, para nos dar essa disposição de indiferença desapegada que age. Os discursos mundiais mesmo que nos transportem para uma urgência imediata não nos fazem agir, as organizações políticas tornaram-se ineficazes e oportunistas. "Há de fato catástrofe, mas a catástrofe consiste nisto: a sociedade dos irmãos ou dos amigos passou por uma tal provação que eles não conseguem já olhar uns para os outros, ou cada um para si próprio, sem um «cansaço», uma desconfiança talvez" (DELEUZE; GUATTARI, 1992, p.96). Talvez por isso se reduza o nosso campo de visão, a nossa percepção, a nossa disposição para agir, o nosso corpo. Aumenta a nossa desconfiança, mas diminui o que ouvimos, vemos menos, perdemos o olfato, afastamo-nos do táctil. Com este corpo, assim aumentado e diminuído, não conseguimos acreditar que as catástrofes ambientais possam ter sido causadas por nós, ou que nos estejamos mesmo a afastar dessa realização espantosa que é a vida.

Partiu-se qualquer coisa, a ruptura abre-se de tal modo que o intolerável a está a deixar marcada e bem inscrita, e nós ("o terrível homem de bem", "o incerto e o indiferente", "o terrível homem do mal" e "o homem da crença") todos, apesar das inscrições bem fundas nos corpos, não acreditamos e deixamo-nos ficar passivos. Proclamamos de forma estridente que pensamos. Mas estamos desconectados da ação. E não é porque as ciências e as religiões tenham resolvido os problemas. Todos os dias descobrimos algo de insuportável, que vai "para além do limite" (DELEUZE, 2006, p.13) do que conhecemos, sabemos ou temos fé. O elo, ainda que ausente, que liga o ser humano com o mundo, tem ainda de ser visto e sentido de novo pela crença.

A falta de crença, que é a nossa, parte as cadeias fundamentais que nos atam à vida. O problema tornou-se tão crítico que não se resolve já com uma "mudança nos nossos corações" ou uma "tomada de consciência" (DELEUZE, 2006, p.35). Parece demasiado tarde para insistir num processo tão lento e com tantos meandros labirínticos por desembaraçar.

Alguns sabem "retirar do acontecimento a parte irredutível àquilo que 
acontece: (...) a parte do visionário" (DELEUZE, 2006, p.35).

Como é que ainda não conseguimos ver, todos e não só alguns, o que estamos a fazer ao planeta? Como não ver o que nos acontece concretamente há mais de um ano? E nos está a acontecer a todos! Como não ver as mortes? As infâmias, a ganância? O sofrimento? O fenômeno é mundial, seja em África ou nas Américas, na Austrália ou na zona mais recôndita da Terra. Como não ver, o que podemos traduzir numa palavra -, o intolerável? O insuportável que nos absorve todas as forças e nos retira da vida. O que nos impede de acreditar que outras ações que são também nossas, imediatas ou não, produzam a destruição geral e a nossa própria extinção? Por que ficamos mudos e passivos, indiferentes e cegos? Estamos à beira de tanta coisa, da morte, da doença, de acidentes sem retorno, da fome, da pobreza... $E$, no entanto, avançamos tão convictos do conforto que as (in) finitas explicações racionais nos dão quando ambicionam mapear o universo todo. E temos meios bem desenvolvidos de ver, reconhecer e aceitar. Suportamos, pois, apesar de tudo, a servidão mundial, a miséria, a injustiça, as desigualdades, com "esquemas" pouco consistentes, desviamo-nos quando não nos agrada, para nos conformarmos, para nos escondermos. Quando se perde um elo que deita tudo a perder, quando se estilhaça a comunidade, quando o ego alastra qual catástrofe descontrolada, o que pode fazer a diferença?

Para Deleuze, a "nova crença" que age e faz e que não é só "blá blá blá" 1 implica "acreditar, não num outro mundo, mas no elo do homem e do mundo" (DELEUZE, 2006, p.219), ela é mesmo uma espécie rara de pensamento do impensável. Precisamos de acreditar na vida e deixar de julgar que estamos num outro mundo.

A crença é o próprio elo, e, fina como é, desenha com a infinita delicadeza que é capaz de abrir passagens impossíveis. A ação de desenhar também o faz, é uma espécie de crença. Pode perguntar-se como se consegue fazer? Van Gogh na voz de Artaud define o que é desenhar:

"É a ação de abrir passagem através de um invisível muro de ferro, que parece interpor-se entre o que se sente e o que é possível realizar" (ARTAUD, 1990, p. 36).

É toda uma conversão da crença, que, imanente à vida, enquanto se muda a si mesma, realiza e realiza-se abrindo passagens através dos visíveis e invisíveis muros que construímos.

Como potência, como conceito de articulação fina, quer dizer, como prática ou como práticas, diz respeito à maneira como comemos, como viajamos, como tomamos decisões políticas, como amamos, como morremos. A crença ou as crenças põem-se em prática. São coletivas, e como cola subtil e plástica, ligam-nos e desligam-nos e põem-nos num lugar, têm alcance prático, pode até ser implícito, sem representação e impessoal.

A crença é uma força, um fazer inseparável do dizer, inseparável do corpo. Porque é também uma potência própria e paradoxal do pensamento-corpo, mesmo que talvez ainda não a saibamos usar ou usemos desajeitadamente. Com mil variantes, estamos neste contexto a olhar para uma das suas faces: a crença na vida, no mundo. Fazer inseparável que torna a possibilidade, sempre renovada, de

\footnotetext{
${ }^{1}$ https://www.theguardian.com/environment/2021/sep/28/blah-greta-thunberg-leaders-
} climate-crisis-co2-emissions 
perpetuar a vida, numa realidade.

Deleuze referir-se-á a Bergson para tornar mais vívida a dúvida que sempre tivemos ou suspeitamos:

"(...) nós não apreendemos a coisa ou a imagem inteira, apreendemo-la sempre menos, apreendemos só aquilo que estamos interessados em apreender, ou melhor, o que temos interesse em apreender, em função dos nossos interesses econômicos, das nossas crenças ideológicas, das nossas exigências psicológicas." (DELEUZE, 2006, p.35)

Pela necessidade urgente que agora temos de refazer e reparar as nossas vidas impõe-se falar da crença. Surge a cada instante o fato, incontornável e comum a todos, diante do qual não fugiremos mais. O fato que só pode ser dado pela crença. Crer neste mundo e não ceder à barbárie que o nega.

Fazer a diferença passa pela conversão da crença. Pelo impossível que só pode ser dado na crença. Talvez possa ser uma questão vital de gosto como Duchamp crê: "Gosto da palavra "crer". Em geral quando dizemos "eu sei", não sabemos, acreditamos. (...) Viver, é crer; é pelo menos o que creio" (DUCHAMP, 1975, p.185).

De que novo coeficiente de subjetividade precisamos? Ou melhor, de que "novos tipos de acontecimentos "ou corpos precisamos? Que luta travamos? Que não é já uma questão de consciência, mas uma questão de fazer num instante, na oportunidade que é preciso aproveitar, nas razões e vontade de sobreviver.

Acreditar no mundo e na vida é acreditar no corpo.

Acreditar no mundo é o primeiro gesto, a primeira atitude do corpo, que nos dispõe a agir e que se pode suscitar com acontecimentos abruptos, que podem ser mesmo muito pequenos. O essencial da crença é infra-discursivo. É aí que se medem e julgam as capacidades de resistência ou ao contrário a submissão e a extinção. Crer no mundo não exige convicção, ou adesão forte, ou atitude psicológica, até se pode ser não crente ou indiferente. "O mundo não se fez para pensarmos nele" dirá Alberto Caeiro, de Fernando Pessoa (1987), em o "Guardador de rebanhos". Mas é sobre ele que temos de concentrar os nossos esforços ou o melhor das nossas forças.

"Só a crença no mundo pode ligar o homem àquilo que ele vê e ouve" (DELEUZE, 2006, p.222). Só a crença enquanto potência expansiva infra-discursiva se pode suster no plano "aquém ou além das palavras" e fazer nascer novos espaçostempos, mesmo que só de superfície e de volume reduzido.

O que parece mais certo e concreto é que acreditar, neste sentido, é o mais vital e básico gesto do corpo. É o espantosamente fácil: "simplesmente acreditar no corpo" (DELEUZE, 2006, p.223) e "entregar o discurso ao corpo, e para isso atingir o corpo antes dos discursos, antes das palavras, antes que as coisas sejam nomeadas" (Ibidem).

A crença aqui vista é imanente, implícita, meio inconsciente, força ou potência que se levanta do chão incandescente e se dispõe a enfrentar as situações mais extremas e dramáticas: os corais que morrem, as geleiras que derretem e deixam de ser eternas, as águas que sobem, os incêndios intermináveis, os incontáveis plásticos nos oceanos, os efeitos, nos corpos das plantas, dos animais, de todos os seres, do calor insustentável. Esta crença inscreve-se na "carne" que dói, que sangra, que seca e adoece e já não respira e morre. 
"Temos de acreditar no corpo, mas como germe de vida, na semente que faz rebentar as pedras, que se conservou, perpetuou no santo sudário ou nas ligaduras da múmia e que testemunha pela vida, numa fé, o que faz rir os idiotas, não é uma necessidade de acreditar noutra coisa, mas uma necessidade de acreditar neste mundo, de que os idiotas fazem parte" (DELEUZE, 2006, p.224).

O que a crença capta e engendra, ao mesmo tempo, só é o mais importante se ela for capaz de se tornar a disposição prática que em cada fazer ultrapassa os obstáculos, se for capaz de não nos fornecer regras protetoras, semelhanças e causalidades. É que "«nós nem sequer sabemos o que pode um corpo»: no sono, na sua ebriedade, nos seus esforços e nas suas resistências" (DELEUZE, 2006, p.243) ou como podem os corpos juntos, que esperam, e porque já não têm tempo na terra, pôr tempo em si mesmos: as crianças, as mulheres, os indígenas, os animais, as plantas... e como lançam fios de invenções insondáveis para sobreviver ao fim do mundo. Sim a crença não é real, nem imaginária, nem quotidiana, nem cerimonial. É talvez ecológica, impessoal e estende-se por toda a Terra para além de nós. 


\section{Referências}

ARTAUD, Antonin. Van Gogh o suicidado pela sociedade. Rio de janeiro: Achiamé, 1990.

DELEUZE, Gilles. Empirisme et subjectivité. Paris: PUF, 1953.

DELEUZE, Gilles. A imagem-Tempo. Lisboa: Assírio \& Alvim, 2006.

DELEUZE, Gilles; Guattari, Félix. O que é a Filosofia?. Lisboa: Presença, 1992.

DUCHAMP, Marcel. Duchamp du signe. Écrits. M. Sanouillet e E. Peterson (eds.), Paris : Flammarion, 1975.

LATOUR, Bruno. L'espoir de Pandore. Pour une version réaliste de l'activité scientifique. Paris: La Découverte, 2007.

PESSOA, Fernando. Poemas de Alberto Caeiro. Lisboa: Ática, 1987. 